\title{
Facile Preparation of 1,2-Diols from Chalcones: An NMR Spectroscopy and X-Ray Crystallography Study
}

\author{
Marco A. Obregón-Mendoza1, María Miriam Estévez-Carmona1, \\ Carolina Escobedo-Martínez ${ }^{2}$, Manuel Soriano-García1* ${ }^{*}$, Raúl G. Enríquez ${ }^{{ }^{*}}$ \\ ${ }^{1}$ Instituto de Química, Universidad Nacional Autónoma de México, Ciudad Universitaria, México City, México \\ ${ }^{2}$ Departamento de Farmacia, División de Ciencias Naturales y Exactas del Campus Guanajuato, Universidad de \\ Guanajuato, México \\ Email: ${ }^{*}$ habib@unam.mx, ${ }^{*}$ soriano@unam.mx
}

Received 8 April 2015; accepted 18 July 2015; published 21 July 2015

Copyright (C) 2015 by authors and Scientific Research Publishing Inc.

This work is licensed under the Creative Commons Attribution International License (CC BY).

http://creativecommons.org/licenses/by/4.0/

(c) (i) Open Access

\section{Abstract}

Structures of 2-(naphthalen-2-ylmethyl)-2,3-dihydro-1H-indene-1,2-diol $\left(\mathrm{C}_{20} \mathrm{H}_{18} \mathrm{O}_{2}\right)$, compound 1 and 1-(3,4-dimethoxyphenyl)-3-methoxy-3-(4-nitrophenyl)propane-1,2-diol chloroform $\left(\mathrm{C}_{18} \mathrm{H}_{21} \mathrm{NO}_{7} \cdot \mathrm{CHCl}_{3}\right)$ compound 2 were established by spectral and X-ray diffraction studies. Compound 1 crystallizes in the orthorhombic space group P2 $2_{1} 2_{1} 2_{1}$ with unit cell parameters $a=5.2177(6), b=13.903(2), c=$ 21.121 (2) $\AA, Z=4$. Compound 2 crystallizes in the triclinic space group $P-1$ with unit cell parameters $a=9.238$ (1), $b=9.879$ (1), $c=12.636$ (1) $\AA, \alpha=102.004$ (1), $\beta=92.356$ (1), $\gamma=90.779(1)^{\circ}, \mathrm{Z}=$ 2. These two new molecules arise from a facile preparation of 1,2-diols from chalcones and have been fully characterized. Based on the crystallographic information obtained for compound 1 , the relative configuration for the chiral centers is $1 S$ and $2 S$. In structure 1 , both hydroxyl groups adopt an anti-conformation with a torsion angle 01-C1-C2-02 value of 93.1 (2) ${ }^{\circ}$ [in molecule 2 , both hydroxyl groups adopt a trans-conformation with a torsion angle 01-C1-C2-02 value of $\left.-171.0(2)^{\circ}\right]$. In both structures, the molecules in the crystal are linked by intermolecular hydrogen bonds $\mathrm{O}-\mathrm{H} \cdots \mathrm{O}$ and $\mathrm{C}-\mathrm{H} \cdots \mathrm{O}$ interactions and adjacent molecules are interconnected by intermolecular weak $\mathrm{C}-\mathrm{H} \cdots \pi$ and $\mathrm{C}-\mathrm{H} \cdot \cdots \mathrm{Cl}$ interactions which give additional support to molecular packing stability.

\section{Keywords}

$\mathrm{C}_{20} \mathrm{H}_{18} \mathrm{O}_{2}, \mathrm{C}_{18} \mathrm{H}_{21} \mathrm{NO}_{7} \cdot \mathrm{CHCl}_{3}$ Diols, Chalcones

\footnotetext{
${ }^{*}$ Corresponding authors.
}

How to cite this paper: Obregón-Mendoza, M.A., Estévez-Carmona, M.M., Escobedo-Martínez, C., Soriano-García, M. and Enríquez, R.G. (2015) Facile Preparation of 1,2-Diols from Chalcones: An NMR Spectroscopy and X-Ray Crystallography Study. International Journal of Organic Chemistry, 5, 137-146. http://dx.doi.org/10.4236/ijoc.2015.53015 


\section{Introduction}

In the field of organic chemistry, there is a need to optimize stereospecific reactions in order to get the desired products within a high yield. The synthesis of diols from carbonyl derivatives has been widely used mainly as a previous step for introducing carbon-carbon double bonds, since these methods allow the control of stereochemistry and the position of unsaturation [1]. On the other hand, 1,2-diols are found frequently in natural products in carbohydrates, polyketides, and alkaloids, and for this reason modern synthetic methods of natural products involve enantioselective or catalytic asymmetric procedures [2]. The use of metal hydrides on reduction of ketones to alcohols has been invaluable in the synthesis of diols which is commonly carried out in acidic medium [3]. The use of borohydride gives a selective reduction from $\alpha, \beta$-unsaturated ketones to allylic alcohols [4].

Chalcones or 1,3-diphenylprop-2-en-1-ones are compounds present in plants which are readily synthetized. They are $\alpha, \beta$-unsaturated ketones with preferential reactivity towards thiols in contrast to amino and hydroxyl groups [5] [6].

Here we report two new molecules that arise from a facile preparation of 1,2-diols from chalcones and have been fully characterized by NMR and X-ray crystallography techniques.

\section{Experimental}

All the chemicals were of reagent grade and were used as received. Solvents were purified by standard methods [7]. Precursors 3'-(naphthalen-2-yl)spiro[indene-2,2'-oxiran]-1(3H)-one was obtained using peroxide of hydrogen and oxidizing double bond of the precursor chalcone and 1-(3,4-dimethoxyphenyl)-2-hydroxy-3-methoxy3-(4-nitrophenyl)propan-1-one was obtained using an opening of the precursor epoxide with methanol and sulphuric acid in reflux.

\subsection{Physical Measurements}

Melting points were determined in on Fisher-Jones melting point apparatus and are uncorrected. IR absorption spectra were recorded in the $4000-400 \mathrm{~cm}^{-1}$ range as $\mathrm{KBr}$ pellets on a Perkin Elmer 283-B spectrophotometer. ${ }^{1} \mathrm{H}$ and ${ }^{13} \mathrm{C}$ NMR spectra were recorded in $\mathrm{CDCl}_{3}$ and $\mathrm{DMSO}-\mathrm{d}_{6}$ on a Unity Varian $300 \mathrm{MHz}$ or $500 \mathrm{MHz}$ spectrometer using TMS as an internal reference.

\subsection{Synthesis of Compounds}

2-(Naphthalen-2-ylmethyl)-2,3-dihydro-1H-indene-1,2-diol (1)

In a $100 \mathrm{~mL}$ of a round-bottom flask, $0.5 \mathrm{mmol}$ of recrystallized 3'-(naphthalen-2-yl)spiro[indene-2,2'-oxiran]-1(3H)-one was suspended in $50 \mathrm{~mL}$ of distilled ethyl ether at $0^{\circ} \mathrm{C}$ with magnetic stirring. Then, $2 \mathrm{mmol}$ of $\mathrm{LiAlH}_{4}$ suspended in $10 \mathrm{~mL}$ of ether were added and the mixture was allowed to react for $3 \mathrm{~h}$, followed by SiO${ }_{2}$ TLC. After acidification with $10 \% \mathrm{HCl}$, the extraction and evaporation of the organic solvent, a crystalline solid $\mathrm{mp}=176^{\circ} \mathrm{C}$ was obtained which was recrystallized from ethyl acetate: Hexane and 86\% yield. ${ }^{1} \mathrm{H}$ NMR (300 $\mathrm{MHz} \mathrm{CDCl}_{3}$-DMSO): $\delta 2.54$ (d,1H, J 15.6Hz, CH $) 3.01$ (d,1H,J 15.9Hz, CH 1H, J $14.4 \mathrm{CH}_{2}$ ), 4.22 (s, 2H, C-OH), 5.0 (s, 1H, C-H), $7.08-7.22$ (m, 2H, C aryl H), 7.22 - 7.42 (m, $\left.2 \mathrm{H}, \mathrm{C}_{\text {aryl }} \mathrm{H}\right)$, $7.42-7.53\left(\mathrm{~m}, 4 \mathrm{H}, \mathrm{C}_{\text {aryl }} \mathrm{H}\right), 7.72-7.81\left(\mathrm{~m}, 2 \mathrm{H}, \mathrm{C}_{\text {aryl }} \mathrm{H}\right), 8.03\left(\mathrm{~d}, 1 \mathrm{H}, \mathrm{J} 6.6 \mathrm{~Hz}, \mathrm{C}_{\text {aryl }} \mathrm{H}\right),{ }^{13} \mathrm{CNMR}\left({ }^{13} \mathrm{C}\{1 \mathrm{H}\} 75.5\right.$ MHz, CDCl 3 -DMSO): $\delta 34.5(\mathrm{C}-\mathrm{H}), 40.9(\mathrm{C}-\mathrm{H}), 82.5((\mathrm{C}-\mathrm{H}),(\mathrm{C}-\mathrm{OH})), 84.5(\mathrm{C}-\mathrm{OH}), 124.1\left(\mathrm{C}_{\text {aryl }} \mathrm{H}\right), 124.3\left(\mathrm{C}_{\mathrm{a}-}\right.$ ryl H), $124.6\left(\mathrm{C}_{\text {aryl }} \mathrm{H}\right), 124.7\left(\mathrm{C}_{\text {aryl }} \mathrm{H}\right), 124.7\left(\mathrm{C}_{\text {aryl }} \mathrm{H}\right), 124.8\left(\mathrm{C}_{\text {aryl }} \mathrm{H}\right), 126.0,\left(\mathrm{C}_{\text {aryl }} \mathrm{H}\right), 126.0\left(\mathrm{C}_{\text {aryl }} \mathrm{H}\right), 127.3\left(\mathrm{C}_{\text {aryl }} \mathrm{H}\right)$, $127.8\left(\mathrm{C}_{\text {aryl }} \mathrm{H}\right), 128.5\left(\mathrm{C}_{\text {aryl }} \mathrm{H}\right), 132.2\left(\mathrm{C}_{\text {aryl }}\right), 133.1\left(\mathrm{C}_{\text {aryl }}\right), 133.2\left(\mathrm{C}_{\text {aryl }}\right), 140.1\left(\mathrm{C}_{\text {aryl }}\right), 143.9\left(\mathrm{C}_{\text {aryl }}\right), \operatorname{IR}(1122.86$ $\mathrm{cm}^{-1}, 1596.43 \mathrm{~cm}^{-1}, 1927.62 \mathrm{~cm}^{-1}, 2873.83 \mathrm{~cm}^{-1}, 3058.53 \mathrm{~cm}^{-1}, 3283.09 \mathrm{~cm}^{-1}$ ), EM: M+ 290 (calc. exact mass 290.36) (Scheme 1).<smiles>O=C1c2ccccc2CC12OC2c1ccc2ccccc2c1</smiles>

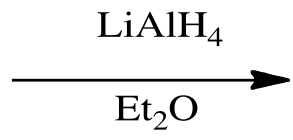

$0^{\circ} \mathrm{C}, 3 \mathrm{~h}$<smiles>OC1c2ccccc2CC1(O)Cc1ccc2ccccc2c1</smiles>

(1)

Scheme 1. The preparation of compound 1. 
1-(3,4-Dimethoxyphenyl)-3-methoxy-3-(4-nitrophenyl)propane-1,2-diol carbon tetra chloride (2)

In a $100 \mathrm{~mL}$ of a round-bottom flask, $0.5 \mathrm{mmol}$ of recrystallized 1-(3,4-dimethoxyphenyl)-2-hydroxy-3-methoxy-3-(4-nitrophenyl)propan-1-one was suspended in $50 \mathrm{~mL}$ of distilled THF at $0^{\circ} \mathrm{C}$ with magnetic stirring. Then, $0.25 \mathrm{mmol}$ of $\mathrm{NaBH}_{4}$ suspended in $10 \mathrm{~mL}$ of THF were added and the mixture allowed reacting for 30 mins, followed by $\mathrm{SiO}_{2}$ TLC. After acidification with $10 \% \mathrm{HCl}$ and the extraction and evaporation of the organic solvent, a crystalline solid $\mathrm{mp}=124.5^{\circ} \mathrm{C}$ was obtained which was recrystallized from chloroform: hexane with 95\% yield. ${ }^{1} \mathrm{H}$ NMR (300 MHz CDCl ${ }_{3}$ ): $\delta 1.762$ (s, $\left.1 \mathrm{H}, \mathrm{C}-\mathrm{OH}\right), 3.015$ (s, $\left.1 \mathrm{H}, \mathrm{C}-\mathrm{OH}\right), 3.279$ (s, 3H, $\mathrm{CH}_{3}$ ),

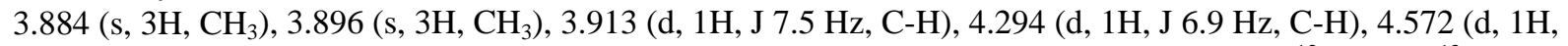
J 7.2 Hz, C-H), $6.926\left(\mathrm{~m}, 3 \mathrm{H}, \mathrm{C}_{\text {ary }} \mathrm{H}\right), 7.599\left(\mathrm{~d}, 2 \mathrm{H}, \mathrm{J} 8.7 \mathrm{C}_{\text {ary }} \mathrm{H}\right), 8.223\left(\mathrm{~d}, 2 \mathrm{H}, \mathrm{J} 8.7 \mathrm{C}_{\text {aryl }} \mathrm{H}\right),{ }^{13} \mathrm{CNMR}\left({ }^{13} \mathrm{C}\{1 \mathrm{H}\}\right.$ $\left.75.5 \mathrm{MHz}, \mathrm{CDCl}_{3}\right): \delta 55.862\left(\mathrm{CH}_{3}\right), 55.906\left(\mathrm{CH}_{3}\right), 57.071\left(\mathrm{CH}_{3}\right), 75.631(\mathrm{C}-\mathrm{OH}), 76.403\left(\mathrm{C}-\mathrm{OCH}_{3}\right), 84.677$ $(\mathrm{C}-\mathrm{OH}), 110.185\left(\mathrm{C}_{\text {aryl }} \mathrm{H}\right), 110.987\left(\mathrm{C}_{\text {aryl }} \mathrm{H}\right), 119.873\left(\mathrm{C}_{\text {aryl }} \mathrm{H}\right), 123.384\left(\mathrm{C}_{\text {aryl }} \mathrm{H}\right), 128.512\left(\mathrm{C}_{\text {ary }} \mathrm{H}\right), 128.890\left(\mathrm{C}_{\text {aryl }}\right)$, $132.459\left(\mathrm{C}_{\text {aryl }}\right), 146.007\left(\mathrm{C}_{\text {ary }}\right), 147.843\left(\mathrm{C}_{\text {aryl }}\right), 149.140\left(\mathrm{C}_{\text {ary }}\right), \operatorname{IR}:\left(1262.64 \mathrm{~cm}^{-1}, 1346.99 \mathrm{~cm}^{-1}, 1518.96 \mathrm{~cm}^{-1}\right.$, $2934.76 \mathrm{~cm}^{-1}, 3474.43 \mathrm{~cm}^{-1}$ ), EM:M+ 363 (calc. exact mass. 363.13) (Scheme 2).<smiles>COc1ccc(C(=O)C(O)C(OC)c2ccc([N+](=O)[O-])cc2)cc1OC</smiles>

Scheme 2. The preparation of compound 2.

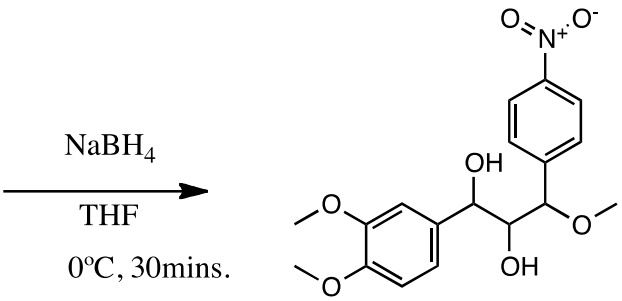

(2)

\subsection{Determination of the Crystal Structures}

Both X-ray data were collected on a Bruker Smart APEX AXS CCD area detector with a graphite monochromator and Mo $\mathrm{K} \alpha$ radiation $(\lambda=0.71073 \AA)$ at room temperature by the $\omega$ scan mode. All collected data were reduced using SAINT [8] and the empirical absorption corrections were performed using SADABS program [8]. The details were shown in Table 1.

\section{Results and Discussion}

\subsection{Refinement Details}

All reflections were defined based on $\mathrm{F}^{2}$. The weighted $\mathrm{R}$-factor $\mathrm{wR}$ and goodness of fit $\mathrm{S}$ are based on $\mathrm{F}^{2}$, conventional R-factors $R$ are based on $F$, with $F$ set to zero for negative $F^{2}$. The threshold expression of $F^{2}>\sigma\left(F^{2}\right)$ is used only for calculating R-factors (gt) etc., and is not relevant to the choice of reflections for refinement. $\mathrm{R}$-factors based on $\mathrm{F}^{2}$ are statistically about twice as large as those based on $\mathrm{F}$, and R-factors based on all data will be even larger.

\subsection{Geometric Details}

All esds (except the esd in the dihedral angle between two l.s. planes) are estimated using the full covariance matrix. The cell esds are taken into account individually in the estimation of esds in distances, angles and torsion angles; correlations between esds in cell parameters are only used when they are defined by crystal symmetry. An approximate (isotropic) treatment of cell esds is used for estimating esds involving l.s. planes.

\subsection{Structure Details}

Both structures were solved by direct methods [9], and then refined by full-matrix least-squares technique; the position and anisotropic parameters of all the non-hydrogen atoms were obtained.

For compound 1, the Flack [10] absolute structure parameter $=0.3(2)$ and its absolute configuration is inferred from the known stereochemistry of 3'-(naphthalen-2-yl)spiro[indene-2,2'-oxiran]-1(3H)-one compound deduced from chemical studies. All relevant tables and figures are based on this configuration. Table 2 showed some crystal and refinement parameters. Atomic coordinates and displacement parameters of both compounds 
were shown in Table 3 and Table 4, these data the structures were gained, which was shown in Figure 1. This figure was drawn with 50\% displacement ellipsoids using ORTEP-3 for Windows [11]. The geometry of the molecule was calculated using the WinGX [12] and PARST [13] [14] software's.

In both structures, the bond distances and bond angles are in good agreement with the corresponding values are within normal ranges. For molecule 1, both hydroxyl groups adopt an anti conformation with a torsion angle O1-C1-C2-O2 value of 93.1 (2) $)^{\circ}$ in molecule 2, both hydroxyl groups adopt a trans conformation with a torsion angle O1-C1-C2-O2 value of $\left.-171.0(2)^{\circ}\right]$. In structures 1 the angle and torsion angles that define the central $\mathrm{C}$ atom that connects to external naphthalene and indene rings C2-C10-C11, C1-C2-C10-C1 and C2-C10-C11-C12

Table 1. Data collection and handling.

\begin{tabular}{ccc}
\hline & Compound $\mathbf{1}$ & Compound 2 \\
\hline Empirical formula & $\mathrm{C}_{20} \mathrm{H}_{18} \mathrm{O}_{2}$ & $\mathrm{C}_{19} \mathrm{H}_{22} \mathrm{O}_{7} \mathrm{NCl}_{3}$ \\
Formula weight & 290.34 & 482.73 \\
Crystal external appearance & Colorless, needle & Colorless, block \\
Crystal size & $0.49 \times 0.09 \times 0.08 \mathrm{~mm}$ & $0.26 \times 0.21 \times 0.19 \mathrm{~mm}$ \\
Diffractometer & Bruker Smart APEX AXS & Bruker Smart APEX AXS \\
& CCD area detector & CCD area detector \\
Theta range for data collection & 1.75 to 27.49 deg & 1.65 to 25.37 deg \\
Wavelength & MoKa radiation (0.71073 A) & MoKa radiation (0.71073 $\AA$ ) \\
Programs & SHELXS-97, SHELXL-97 & SHELXS-97, SHELXL-97 \\
Refinement method & Full-matrix least-squares on F2 & Full-matrix least-squares on F2 \\
Absorption correction & Sadabs, Sheldrick, G. M. (1996) & Sadabs, Sheldrick, G. M. (1996) \\
\hline
\end{tabular}

Table 2. Crystal and refinement parameters.

\begin{tabular}{|c|c|c|}
\hline & Compound 1 & Compound 2 \\
\hline \multirow[t]{2}{*}{ Crystal system, } & Orthorhombic & Triclinic \\
\hline & $a=5.2177$ (6) $\AA$ alpha $=90.00 \mathrm{deg}$ & $a=9.2380$ (10) $\AA$ alpha $=102.004$ (1) deg \\
\hline \multirow[t]{2}{*}{ Unit cell dimensions } & $b=13.903(2) \AA$ beta $=90.00 \mathrm{deg}$ & $b=9.8790$ (10) $\AA$ beta $=92.356$ (1) deg \\
\hline & $c=21.121(2) \AA$ gamma $=90.00 \mathrm{deg}$ & $\begin{array}{c}c=12.6360(10) \AA \\
\text { gamma }=90.779(1) \mathrm{deg}\end{array}$ \\
\hline Volume & $1532.2(3) \AA^{3}$ & $1126.7(2) \AA^{3}$ \\
\hline Z, calculated density & $4,1.259 \mathrm{mg} / \mathrm{m}^{3}$ & $2,1.423 \mathrm{mg} / \mathrm{m}^{3}$ \\
\hline Absorption coefficient & $0.080 \mathrm{~mm}^{-1}$ & $0.446 \mathrm{~mm}^{-1}$ \\
\hline Space group & $\mathrm{P} 2{ }_{1} 2_{1} 2_{1}$ & $\mathrm{P}-1$ \\
\hline Limiting indices & $-6 \leq \mathrm{h} \leq 6,-18 \leq \mathrm{k} \leq 17,-27 \leq 1 \leq 27$ & $-11 \leq \mathrm{h} \leq 11,-11 \leq \mathrm{k} \leq 11,-15 \leq 1 \leq 15$ \\
\hline Reflections collected/unique & $15398 / 3527$ [R (int) $=0.0965]$ & $12751 / 4131[\mathrm{R}$ (int) $=0.0346]$ \\
\hline Completeness to theta $=25.10$ & $99.90 \%$ & $99.90 \%$ \\
\hline Max. and min. transmission & 0.9941 and 0.9745 & 0.9304 and 0.8937 \\
\hline Goodness-of-fit on $\mathrm{F}^{2}$ & 0.981 & 0.963 \\
\hline Extinction coefficient & None & None \\
\hline Largest diff. peak and hole & 0.141 and -0.115 e. $\AA^{-3}$ & 0.357 and -0.300 e. $\AA^{-3}$ \\
\hline
\end{tabular}


Table 3. Atomic coordinates and displacements parameters $\left(\AA^{2}\right)$ for compound $\mathbf{1}$.

\begin{tabular}{|c|c|c|c|c|c|c|c|c|c|}
\hline & $\mathrm{x}$ & $\mathrm{y}$ & $\mathrm{z}$ & U11 & $\mathrm{U} 22$ & U33 & $\mathrm{U} 23$ & U13 & U12 \\
\hline $\mathrm{O} 1$ & $0.3416(3)$ & $0.67606(11)$ & $1.04638(8)$ & $0.0363(12)$ & $0.0421(11)$ & $0.0621(12)$ & $-0.0106(9)$ & $-0.0017(10)$ & $0.0029(10)$ \\
\hline $\mathrm{O} 2$ & 0.9067 (3) & $0.63173(13)$ & $0.98309(9)$ & $0.0344(11)$ & $0.0459(12)$ & $0.0692(12)$ & $0.0038(10)$ & -0.0042 (9) & $-0.0026(10)$ \\
\hline $\mathrm{C} 1$ & $0.5279(5)$ & $0.60069(15)$ & $1.04923(10)$ & $0.0340(15)$ & $0.0452(16)$ & $0.0452(16)$ & $-0.0081(13)$ & -0.0082 & 0.0015 (13) \\
\hline $\mathrm{C} 2$ & 0.6725 (4) & $0.57894(15)$ & 0.98657 (11) & $0.0280(13)$ & $0.0384(15)$ & $0.0426(15)$ & $-0.0007(12)$ & $-0.0037(12)$ & 0.0025 (13) \\
\hline C3 & $0.7390(4)$ & $0.47057(14)$ & $0.99289(10)$ & $0.0399(16)$ & $0.0420(14)$ & $0.0472(15)$ & $0.0033(13)$ & $-0.0075(14)$ & $0.0074(12)$ \\
\hline $\mathrm{C} 4$ & $0.4625(5)$ & $0.33741(17)$ & 1.04735 (11) & $0.068(2)$ & $0.0472(17)$ & $0.0568(18)$ & $0.0003(15)$ & $0.0001(18)$ & $0.0003(16)$ \\
\hline C5 & $0.2729(5)$ & 0.31992 (19) & 1.09150 (13) & $0.067(2)$ & $0.055(2)$ & $0.066(2)$ & 0.0147 (17) & $0.0020(18)$ & $-0.0083(18)$ \\
\hline $\mathrm{C} 6$ & $0.1560(5)$ & $0.3930(2)$ & $1.12400(12)$ & $0.063(2)$ & $0.074(2)$ & $0.0461(18)$ & $0.0130(16)$ & $0.0040(16)$ & $-0.008(2)$ \\
\hline $\mathrm{C} 7$ & $0.2279(5)$ & 0.48759 (18) & $1.11267(11)$ & 0.0532 (19) & $0.0572(19)$ & 0.0415 (16) & $0.0015(14)$ & $0.0021(15)$ & $0.0047(15$ \\
\hline $\mathrm{C} 8$ & $0.4168(5)$ & $0.50472(15)$ & $1.06849(10)$ & $0.0329(15)$ & $0.0430(15)$ & $0.0362(14)$ & $0.0021(13)$ & $-0.0100(12)$ & $0.0027(13)$ \\
\hline C9 & $0.5361(4)$ & $0.43165(16)$ & $1.03626(11)$ & $0.0434(17)$ & $0.0365(14)$ & 0.0405 (15) & $0.0037(12)$ & $-0.0088(14)$ & $0.0003(14)$ \\
\hline $\mathrm{C} 10$ & 0.5065 (4) & 0.60065 (15) & $0.92809(10)$ & $0.0343(15)$ & $0.0379(15)$ & 0.0487 (15) & $0.0003(12)$ & $0.0010(14)$ & $0.0041(12)$ \\
\hline C11 & 0.6267 (5) & 0.57115 (18) & $0.86612(11)$ & $0.0352(16)$ & $0.0499(16)$ & $0.0424(16)$ & $0.0131(13)$ & $-0.0018(13)$ & 0.0037 \\
\hline C12 & $0.8097(5)$ & $0.62776(18)$ & 0.83960 (13) & $0.070(2)$ & $0.0546(18)$ & 0.0517 (18) & $0.0077(15)$ & $0.0024(17)$ & $0.0060(17)$ \\
\hline $\mathrm{C} 13$ & $0.9401(6)$ & $0.6040(2)$ & $0.78348(14)$ & $0.072(2)$ & $0.079(2)$ & $0.072(2)$ & 0.0196 (19) & $0.015(2)$ & $-0.006(2)$ \\
\hline C14 & $0.8826(6)$ & $0.5207(2)$ & $0.75400(13)$ & $0.086(3)$ & 0.089 (3) & $0.052(2)$ & 0.0150 (19) & $0.0189(18)$ & $0.017(2)$ \\
\hline C15 & $0.6279(8)$ & $0.3726(2)$ & $0.74698(14)$ & $0.130(4)$ & $0.072(3)$ & $0.055(2)$ & -0.0045 (19) & $-0.013(2)$ & $0.025(3)$ \\
\hline C16 & $0.4433(8)$ & $0.3140(2)$ & $0.76954(16)$ & $0.153(4)$ & $0.065(3)$ & $0.068(3)$ & $-0.017(2)$ & $-0.051(3)$ & $0.006(3)$ \\
\hline C17 & $0.3085(6)$ & $0.3379(2)$ & $0.82452(16)$ & $0.102(3)$ & $0.059(2)$ & $0.080(2)$ & $0.008(2)$ & $-0.029(2)$ & $-0.013(2)$ \\
\hline C18 & $0.3668(5)$ & $0.4208(2)$ & $0.85596(12)$ & $0.063(2)$ & $0.0572(18)$ & 0.0581 (19) & $0.0022(16)$ & $-0.0108(16)$ & -0.0009 (18) \\
\hline C19 & $0.5598(5)$ & $0.48349(17)$ & $0.83433(11)$ & $0.0458(18)$ & $0.0465(16)$ & 0.0407 (16) & $0.0073(14)$ & $-0.0018(14)$ & 0.0080 \\
\hline $\mathrm{C} 20$ & $0.6924(6)$ & $0.4587(2)$ & $0.77761(12)$ & $0.078(2)$ & $0.056(2)$ & 0.0398 (17) & 0.0006 & $-0.0094(18)$ & 0.0185 \\
\hline
\end{tabular}

are $114.2(2),-173.9$ (2) and -78.9 (3) ${ }^{\circ}$ [in molecule 2, the angle and the torsion angles that define the central C atoms that connects to external phenyl rings C1-C2-C3, C4-C1-C2-C3, C1-C2-C3-C12 are 114.3 (2), -172.5 (2) and $\left.-66.7(2)^{\circ}\right)$ ] respectively. It is apparently that the angle and torsion angle that define the central carbon atoms are similar independently of the side groups involved.

In structure 1, the chiral centers at the $\mathrm{C} 1$ and $\mathrm{C} 2$ atoms are in the S configuration. The mean planes C1-C9, C11-C20; and C1/C4-C9, C3/C12-C17for structures 1 and 2 make dihedral angles of 28.10 (5), 89.72 (6) ${ }^{\circ}$, respectively. In structure 2, the nitro group attached to the C12-C15 phenyl ring is only 6.3 (1) ${ }^{\circ}$ out of the plane, the torsion angles for O6-N1-C15-C14 and O7-N1-C15-C16 are -0.9 (4) and -0.1 (4) ${ }^{\circ}$, respectively. The methoxy group at C3 adopts an intermediate conformation between eclipsed and gauche conformations with respect to the C3/C12-C17 ring, the torsion angle is 33.0 (3) ${ }^{\circ}$. The methoxy groups attached at C6 and C7 lie almost in the plane of the benzene ring to which they are attached C4-C9, the torsion angles C10-O4-C6-C5 and C11-O5-C7-C8 are 2.2 (3) and $8.2(4)^{\circ}$, respectively.

In structure 1, the distances between the Cg gravity centers of naphthalene and indene; between naphthalene symmetry related molecules; and between indene symmetry related rings are 5.20; 5.22 and $4.99 \AA$, respectively. The distance between the Cg gravity center of the ring C4-C9 and the H3B of a symmetry related molecule is $2.79 \AA$.

In structure 2, the distances between the Cg gravity centers of phenyl C4-C9 rings; phenyl rings C4-C9 and C12-C17; phenyl ring C4-C9 and H18B of the methoxy group at C3; and phenyl ring C12-C17 and H18C of the 
Table 4. Atomic coordinates and displacements parameters $\left(\AA^{2}\right)$ for compound 2.

\begin{tabular}{|c|c|c|c|c|c|c|c|c|c|}
\hline & $\mathrm{x}$ & $\mathrm{y}$ & $\mathrm{z}$ & U11 & U22 & U33 & $\mathrm{U} 23$ & U13 & U12 \\
\hline $\mathrm{O} 1$ & $0.6120(2)$ & 0.23565 (19) & $0.81538(17)$ & $0.0794(14)$ & $0.0611(12)$ & $0.0475(12)$ & $0.0134(10)$ & $-0.0083(10)$ & $-0.0118(10)$ \\
\hline $\mathrm{O} 2$ & 36879 (18) & $0421(2)$ & $0.60740(14)$ & $0.0477(10)$ & 0.0435 (11) & $0.0545(11)$ & $0.0061(9)$ & $0.0017(8)$ & $-0.0011(9)$ \\
\hline O3 & 53124 (18) & $0.20801(15)$ & $0.49461(12)$ & $0.0787(12)$ & $0.0440(10)$ & $0.0434(10)$ & $0.0106(8)$ & $0.0179(8)$ & $0.0030(8)$ \\
\hline $\mathrm{O} 4$ & 0.30057 (19) & $-0.21099(18)$ & 0.96169 (14) & $0.0603(12)$ & $0.0710(12)$ & $0.0572(11)$ & $0.0229(9)$ & 0.0109 (9) & $-0.0081(9)$ \\
\hline O5 & $5371(2)$ & -0.34443 (17) & $0.94371(14)$ & $0.0761(13)$ & $0.0565(11)$ & $0.0658(12)$ & $0.0278(9)$ & $0.0028(10)$ & $-0.0003(10)$ \\
\hline O6 & $.1251(3)$ & 0.5089 (3) & $0.6447(2)$ & $0.0814(18)$ & $0.181(3)$ & $0.134(2)$ & $0.043(2)$ & $0.0021(16)$ & 0.0539 (18) \\
\hline O7 & $-0.0249(3)$ & $0.6177(3)$ & $0.7944(3)$ & 0.0937 (19) & $0.114(2)$ & $0.154(3)$ & $-0.0142(19)$ & $0.0383(17)$ & $0.0309(16)$ \\
\hline N1 & $-0.0210(3)$ & $0.5385(3)$ & $0.7069(3)$ & $0.078(2)$ & $0.082(2)$ & $0.107(2)$ & 0.0345 (18) & $0.0209(18)$ & 0.0207 (17) \\
\hline $\mathrm{C} 1$ & 0.4955 (3) & $0.1416(2)$ & 0.77417 (19) & $0.0510(15)$ & $0.0450(14)$ & $0.0457(14)$ & $0.0097(11)$ & $0.0051(11)$ & $-0.0020(12)$ \\
\hline $\mathrm{C} 2$ & $0.4969(2)$ & $0.1182(2)$ & $0.65100(18)$ & $0.0417(13)$ & 0.0407 (13) & $0.0436(14)$ & $0.0080(11)$ & $0.0045(10)$ & $0.0013(11)$ \\
\hline C3 & $0.5055(2)$ & $0.2514(2)$ & $0.60727(18)$ & $0.0509(15)$ & $0.0418(13)$ & $0.0409(14)$ & $0.0064(11)$ & $0.0052(11)$ & $-0.0022(11)$ \\
\hline $\mathrm{C} 4$ & 0.5069 (3) & $0.0076(2)$ & $0.81300(17)$ & $0.0508(15)$ & $0.0491(14)$ & $0.0364(13)$ & 0.0089 (11) & $0.0028(11)$ & 0.0009 (12) \\
\hline C5 & 0.3935 (3) & $-0.0399(2)$ & 0.86605 (18) & $0.0478(14)$ & $0.0513(14)$ & $0.0377(13)$ & $0.0083(11)$ & $0.0040(11)$ & 0.0023 (11) \\
\hline C6 & 0.4059 (3) & $-0.1582(2)$ & 0.90683 (18) & $0.0522(15)$ & $0.0541(15)$ & $0.0349(13)$ & $0.0086(11)$ & $0.0038(11)$ & 3 (13) \\
\hline C7 & 0.5334 (3) & $-0.2320(2)$ & $0.89612(18)$ & $0.0613(17)$ & $0.0430(14)$ & $0.0412(14)$ & $0.0106(11)$ & $-0.0011(12)$ & $-0.0034(12)$ \\
\hline C8 & 0.6445 (3) & -0.1885 (3) & $0.8414(2)$ & $0.0548(16)$ & $0.0557(16)$ & $0.0587(16)$ & 0.0169 (13) & $0.0057(13)$ & 0.0079 (13) \\
\hline $\mathrm{C9}$ & $0.6302(3)$ & $-0.0691(3)$ & $0.8001(2)$ & $0.0533(16)$ & $0.0587(16)$ & $0.0580(16)$ & 0.0227 (13) & $0.0151(12)$ & $0.0021(13)$ \\
\hline C10 & 0.1663 (3) & -0.1405 (3) & $0.9743(2)$ & 0.0593 (19) & 0.109 (2) & $0.069(2)$ & 0.0317 (18) & $0.0157(15)$ & $-0.0071(18)$ \\
\hline C11 & $0.6712(3)$ & $-0.4123(3)$ & 0.9493 (3) & $0.085(2)$ & 0.0691 (19) & 0.099 (2) & 0.0404 (18) & -0.0097 (18) & 0.0076 \\
\hline C12 & $14(3)$ & $2(2)$ & $0.62752(18)$ & 0.0566 (15) & $0.0383(13)$ & $0.0431(14)$ & $0.0122(11)$ & $0.0051(11)$ & 0.0008 (11) \\
\hline C13 & 505 & 0 . & (2) & $0.0708(18)$ & $0.0520(15)$ & $0.0476(15)$ & 0.0109 (12) & -0.0013 & 0.0081 \\
\hline C14 & 0.1236 (3) & 0.3791 (3) & $0.5810(2)$ & $0.0624(18)$ & $0.0700(19)$ & 0.0663 (19) & $0.0229(16)$ & $-0.0057(14)$ & $0.0102(15)$ \\
\hline C15 & $0.1182(3)$ & $0.4722(3)$ & $0.6767(2)$ & 0.0595 (18) & 0.0565 (17) & $0.076(2)$ & $0.0273(15)$ & $0.0160(15)$ & $0.0183(14)$ \\
\hline C16 & 0.2352 (3) & 030 (3) & $482(2)$ & $076(2)$ & $0.0447(15)$ & $0.0626(18)$ & $0.0056(13)$ & $0.0171(15)$ & $0.0111(14)$ \\
\hline C17 & 0.3622 (3) & $0.4345(2)$ & $0.7223(2)$ & $0.0620(17)$ & $0.0441(14)$ & $0.0532(16)$ & $0.0052(12)$ & $0.0006(12)$ & $0.0011(13)$ \\
\hline C18 & 0.5765 (4) & 0.3155 (3) & $0.4431(2)$ & $0.120(3)$ & $0.0597(18)$ & 0.0667 (19) & $0.0247(15)$ & $0.0331(18)$ & 0.0003 (17) \\
\hline C19 & 0.9596 (3) & $9382(3)$ & 3274 (2) & $0.0501(16)$ & $0.102(2)$ & 0.0696 (19) & $0.0283(17)$ & $0.0043(14)$ & $-0.0037(16)$ \\
\hline Cl1 & $1.11226(8)$ & $0.89769(11)$ & $0.40021(8)$ & $0.0561(5)$ & $0.1662(9)$ & $0.1054(7)$ & $0.0613(6)$ & $-0.0027(4)$ & $0.0031(5)$ \\
\hline $\mathrm{Cl} 2$ & $0.94001(10)$ & $0.82527(10)$ & $0.20156(7)$ & $0.0989(7)$ & $0.1206(7)$ & $0.0786(6)$ & $0.0141(5)$ & $0.0146(5)$ & $0.0067(6)$ \\
\hline $\mathrm{Cl} 3$ & $0.97372(11)$ & $1.10876(10)$ & $0.31141(8)$ & $0.1141(8)$ & $0.1031(7)$ & $0.1045(7)$ & $0.0405(6)$ & $-0.0134(5)$ & -0.0159 (6) \\
\hline
\end{tabular}

methoxy group at C3 are 3.93, 6.68 3.11, and $3.25 \AA$, respectively.

The crystal packing in both structures 1 and 2 are dominated by $\mathrm{O}-\mathrm{H} \cdots \mathrm{O}$ hydrogen bonding interactions, with donor-acceptor distances of 2.705 (2) and 2.765 (2) $\AA$; 2.958 (3) and 2.730 (2) $\AA$. In structure 1, these hydrogen bond interactions generate (9) ring motifs [15]. In molecule 1, each molecule is connected to two of its neighbors via intermolecular hydrogen bonds; the packing is viewed down the $c$-axis (Figure 2). The structure is further linked by $\mathrm{C}-\mathrm{H} \cdots \pi$ stacking interactions. 


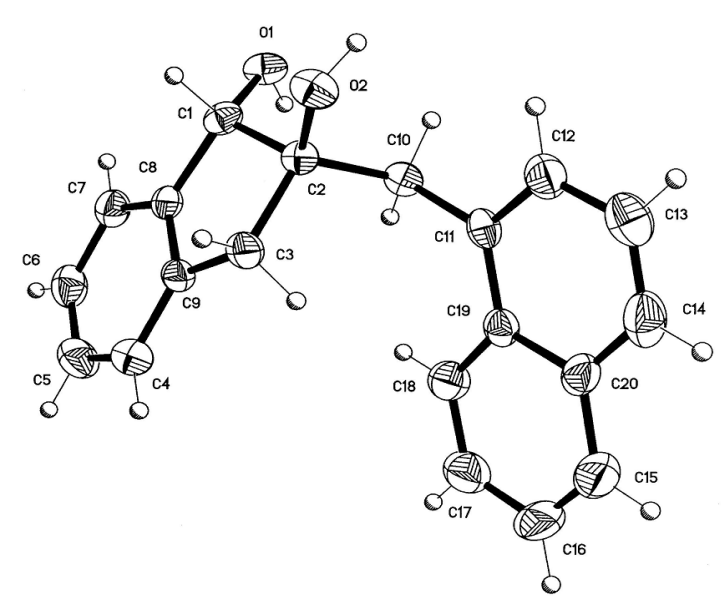

1
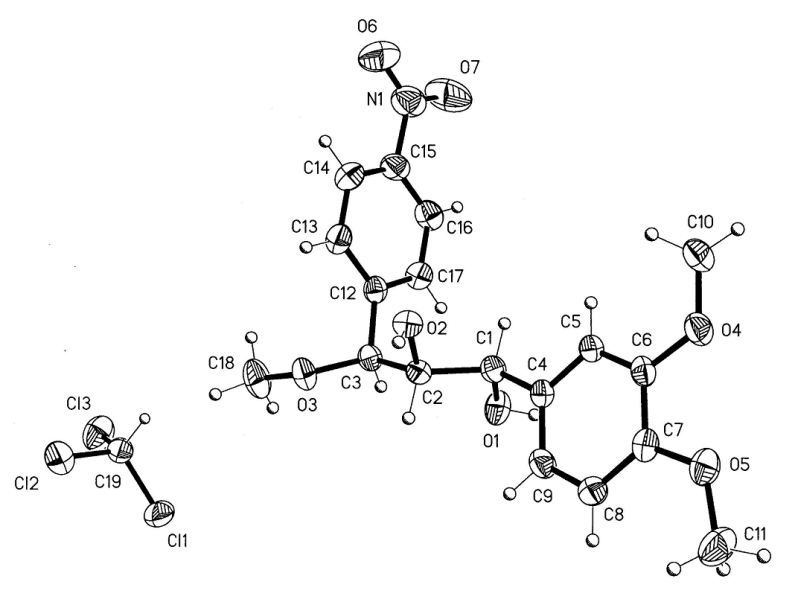

Figure 1. The molecular structures of $\mathbf{1}$ and $\mathbf{2}$.

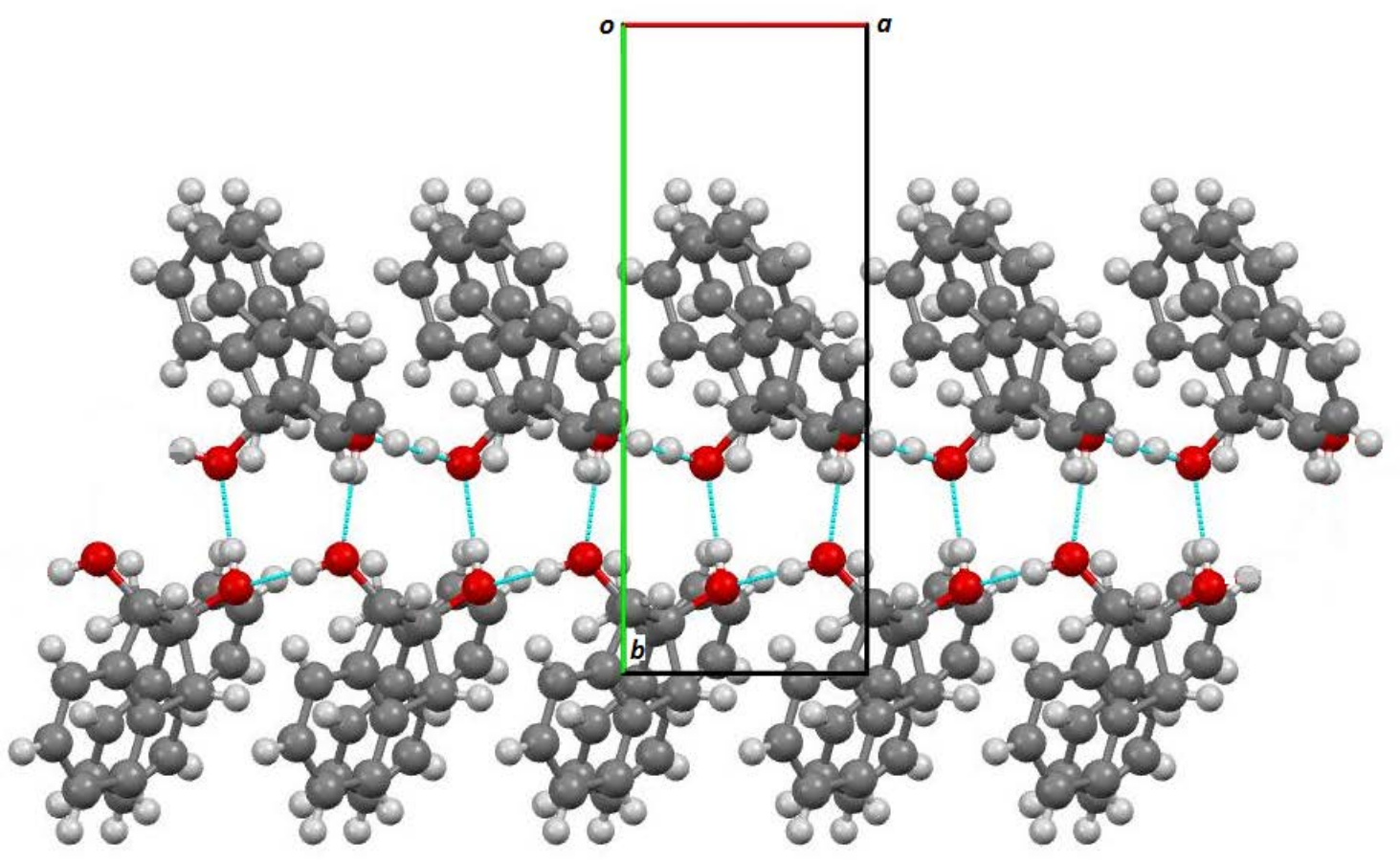

Figure 2. The packing diagram for $\mathbf{1}$ projected along the $c$-axis.

In structure 2 each molecule is connected to one of its neighbors via intermolecular hydrogen bonds, to form a two dimensional supramolecular structure along with the $b c$ crystallographic plane (Figure 3). These hydrogen bond interactions generate two (14) and (10) ring motifs [14]. The structure is linked by C-H $\cdots \pi$ stacking and three $\mathrm{C}-\mathrm{H} \cdots \mathrm{Cl}$ interactions forming a 3D polymer, the $\mathrm{C}-\mathrm{H} \cdots \pi$, distances and angles for $\mathrm{Cg}$ gravity centers to C4-C9 and C12-C17 phenyl rings are given in Figure 4. For geometrical details and notations of all of these hydrogen bonds and intermolecular interactions are given in Table 5 .

\section{Conclusion}

The present study demonstrates the synthesis and chemical characterization by IR, ${ }^{1} \mathrm{H}-\mathrm{NMR}$ and ${ }^{13} \mathrm{C}-\mathrm{NMR}$ spectroscopy of 2-(naphthalen-2-ylmethyl)-2,3-dihydro-1H-indene-1,2-diol $\left(\mathrm{C}_{20} \mathrm{H}_{18} \mathrm{O}_{2}\right)$, compound $\mathbf{1}$ and 1-(3,4-di- 


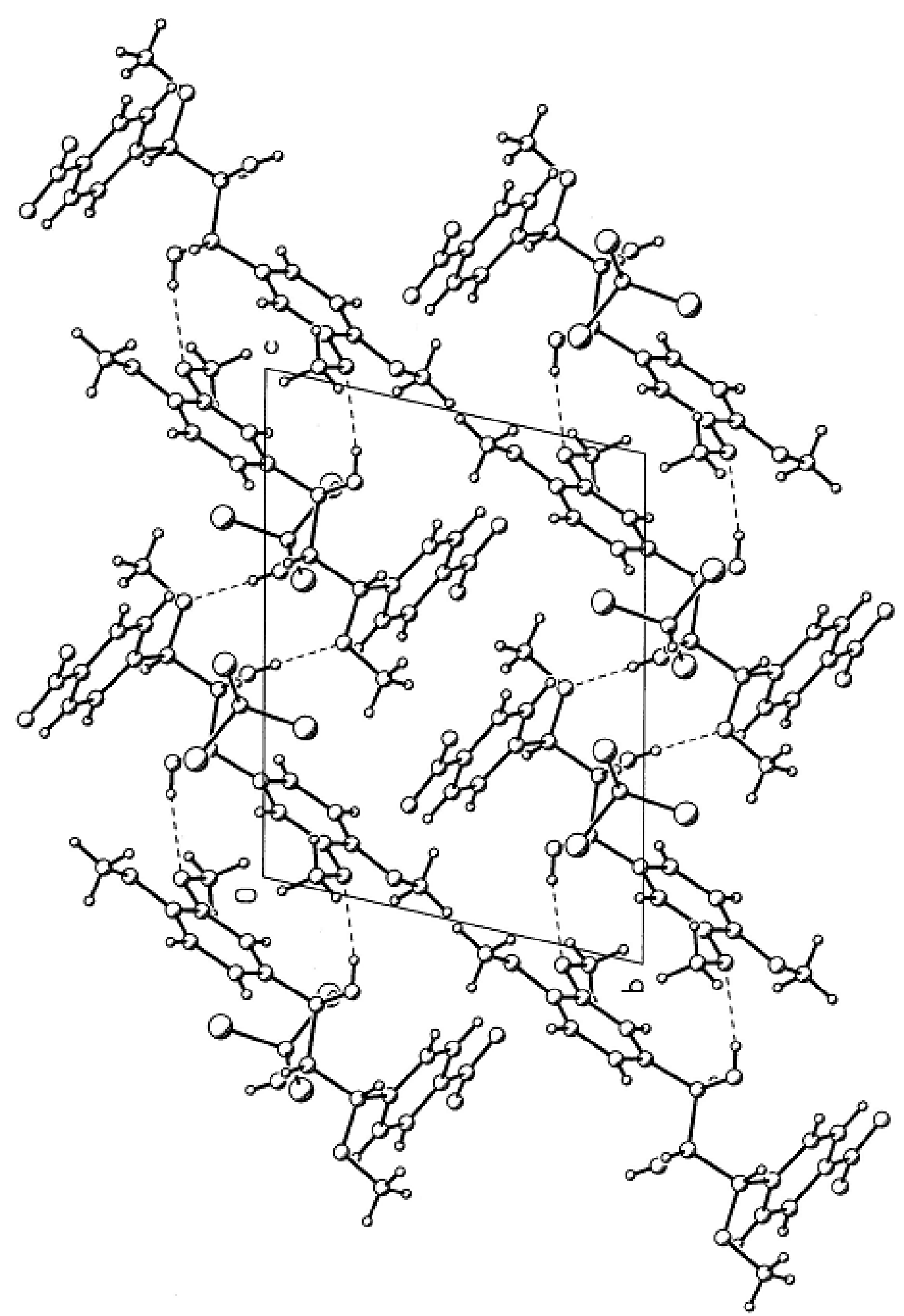

Figure 3. The packing diagram of structure 2 showing the two dimensional supramolecular structure along with the $b c$ crystallographic plane.

methoxy phenyl)-3-methoxy-3-(4-nitrophenyl)propane-1,2-diol chloroform $\left(\mathrm{C}_{18} \mathrm{H}_{21} \mathrm{NO}_{7} \cdot \mathrm{CHCl}_{3}\right)$ compound 2 provides the evidence of facile preparation of 1,2-diols from chalcones. Single crystals of compound $\mathbf{1}$ were 


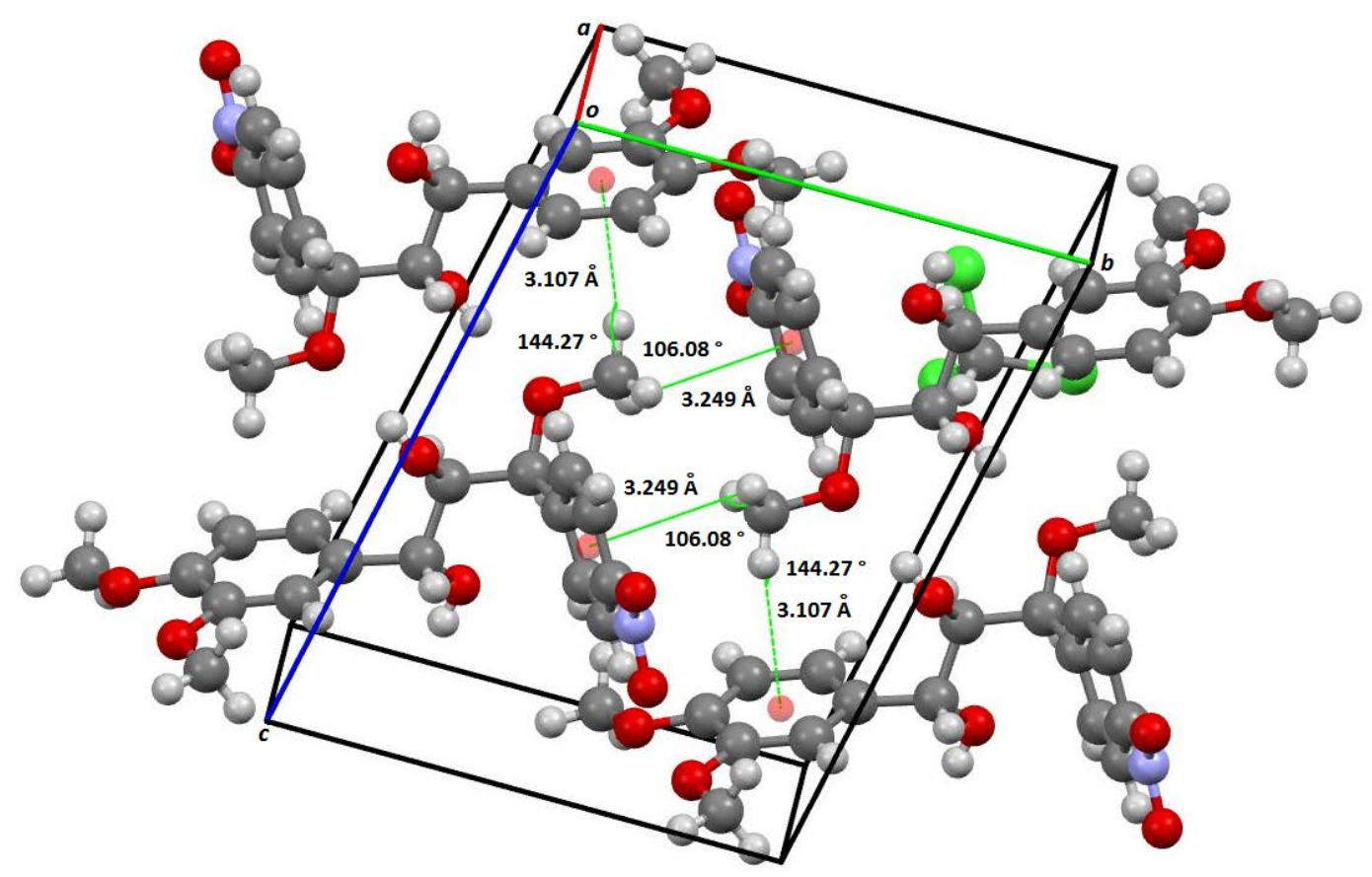

Figure 4. The C-H $\cdots \pi$ stacking interactions between adjacent molecules in structure 2.

Table 5. Geometry of the hydrogen bonds and hydrogen bonding interactions ( $\AA$, º ) for compounds $\mathbf{1}$ and 2.

\begin{tabular}{|c|c|c|c|c|c|}
\hline D-H $\cdot A$ code & D-H & $\mathrm{H} \cdots A$ & $\mathrm{D} \cdots A$ & $\mathrm{D}-\mathrm{H} \cdots A$ & Symmetry code \\
\hline \multicolumn{6}{|l|}{ Compound 1} \\
\hline O1-H1A $\cdots$ O2 & $0.89(2)$ & $1.84(2)$ & $2.705(2)$ & $162(2)$ & $-1+x, y, z$ \\
\hline $\mathrm{O} 2-\mathrm{H} 2 \cdots \mathrm{O} 1$ & $0.83(2)$ & $1.94(2)$ & $2.765(2)$ & $173(2)$ & $1 / 2+x, 3 / 2-y, 2-z$ \\
\hline $\mathrm{C} 10-\mathrm{H} 10 \mathrm{~A} \cdots \mathrm{O} 2$ & $0.970(2)$ & $2.670(2)$ & 3.366 (3) & $128.9(1)$ & $-1+x, y, z$ \\
\hline $\mathrm{C} 12-\mathrm{H} 12 \cdots \mathrm{O} 1$ & $0.930(3)$ & $2.768(2)$ & $3.642(3)$ & $157.1(2)$ & $1 / 2+x, 3 / 2-y, 2-z$ \\
\hline \multicolumn{6}{|l|}{ Compound 2} \\
\hline O1-H1A $\cdots$ O4 & $0.79(4)$ & $2.18(4)$ & $2.958(3)$ & $168(4)$ & $+1-x,-y, 2-z$ \\
\hline $\mathrm{O} 2-\mathrm{H} 2 \mathrm{~A} \cdots \mathrm{O} 3$ & $0.76(3)$ & $1.97(3)$ & $2.730(2)$ & $171(3)$ & $+1-x,-y, 1-z$ \\
\hline $\mathrm{C} 17-\mathrm{H} 17 \cdots \mathrm{O} 1$ & $0.930(3)$ & $2.832(2)$ & $3.381(3)$ & $118.9(2)$ & $x, y, z$ \\
\hline $\mathrm{C} 10-\mathrm{H} 10 \mathrm{C} \cdots \mathrm{O} 7$ & $0.959(2)$ & $2.885(3)$ & $3.360(4)$ & $111.7(2)$ & $x,-1+y,+z$ \\
\hline C19-H9 $\cdots$ O2 & $0.980(3)$ & $2.287(2)$ & $3.174(3)$ & $150.1(2)$ & $1-x,+1-y,+1-z$ \\
\hline $\mathrm{C} 2-\mathrm{H} 2 \cdots \mathrm{Cl} 1$ & $0.979(3)$ & $2.903(2)$ & $3.694(3)$ & $138.4(2)$ & $2-x,+1-y,+1-z$ \\
\hline $\mathrm{C} 10-\mathrm{H} 10 \mathrm{~B} \cdots \mathrm{Cl} 2$ & $0.960(3)$ & $2.885(2)$ & 3.689 (3) & $141.9(2)$ & $1+x,+1+y,-1+z$ \\
\hline $\mathrm{C} 10-\mathrm{H} 10 \mathrm{C} \cdots \mathrm{Cl} 3$ & $0.959(3)$ & $2.903(2)$ & 3.860 (3) & $176.3(2)$ & $1-x,+1-y,+1-z$ \\
\hline
\end{tabular}

The letters A, B and C on $\mathrm{H}$ atoms are only used for identification purposes for instance the hydroxyl and methyl groups.

successfully grown from solution by slow evaporation technique at room temperature using ethyl acetate as a solvent (compound 2, chloroform: hexane). IR and ${ }^{1} \mathrm{H}-\mathrm{NMR}$ are used to confirm the functional groups. During the crystallization process of compound $\mathbf{1}$, the diasteromer (1S and $2 \mathrm{~S}$ ) was obtained while no chiral reagent was used in the reaction. 


\section{Acknowledgements}

We are grateful for technical assistance from RocíoPatiño for IR spectra; Nieves Zavala, Héctor Ríos, Rubén Gaviño and Elizabeth Huerta for RMN spectra, Ruben A. Toscano and Simón Hernández for X-ray determinations; Luis Velasco for EM spectra. Financial support from DGAPA, UNAM project PAPIIT IN216606 is gratefully acknowledged.

\section{References}

[1] Corey, E.J. and Winter, R.A.E. (1963) A New, Stereospecific Olefin Synthesis from 1,2-Diols. Journal of the American Chemical Society, 85, 2677-2678. http://dx.doi.org/10.1021/ja00900a043

[2] Notz, W. and List, B. (2000) Catalytic Asymmetric Synthesis of Anti-1,2-diols. Journal of the American Chemical Society, 122, 7386-7387. http://dx.doi.org/10.1021/ja001460v

[3] Periasamy, M. and Thirumalaikumar, M. (2000) Methods of Enhancement of Reactivity and Selectivity of Sodium Borohydride for Applications in Organic Synthesis. Journal of Organometallic Chemistry, 609, 137-151. http://dx.doi.org/10.1016/S0022-328X(00)00210-2

[4] Fuji, H., Ohima, K. and Utimoto, K. (1991) A Facile and Selective 1,2-Reduction of Conjugated Ketones with $\mathrm{NaBH}_{4}$ in the Presence of $\mathrm{CaCl}_{2}$. Chemistry Letters, 20, 1847-1848. http://dx.doi.org/10.1246/cl.1991.1847

[5] Baluja, M.G., Municio, A.M. and Vega, S. (1964) Reactivity of 1O,p-Unsaturated Ketones toward Sulfhydryl Compounds and Their Antifungal Activity. Chemistry and Industry (London), 50, 2053.

[6] Dimmock, J.R., Raghavan, S.K., Logan, B.M. and Bigam, G.E. (1983) Antileukemic Evaluation of Some Mannich Bases Derived from 2-Arylidene-1,3-diketones. European Journal of Medicinal Chemistry, 18, 248-254.

[7] Armarego, W.L.F. and Perrin, D.D. (1997) Purification of Laboratory Chemicals. 4th Edition, Butterworth-Heinemann, Oxford.

[8] Bruker (2009) APEX2, SAINT and SADABS. Bruker AXS Inc., Madison.

[9] Sheldrick, G.M. (2007) A Short History of SHELX. Acta Crystallographica, A64, 112-122. http://dx.doi.org/10.1107/S0108767307043930

[10] Flack, H.D. (1983) Onenantiomorph-Polarity Estimation. Acta Crystallographica, A39, 876-881. http://dx.doi.org/10.1107/S0108767383001762

[11] Brandenburg, K. (2006) DIAMOND. Version 3.1c. Crystal Impact GbR, Bonn.

[12] Farrugia, L.J. (2012) WinGX and ORTEP for Windows: An Update. Journal of Applied Crystallography, 45, 849-854. http://dx.doi.org/10.1107/S0021889812029111

[13] Nardelli, M. (1983) PARST: A System of Fortran Routines for Calculating Molecular Structure Parameters from Results of Crystal Structure Analyses. Computers \& Chemistry, 7, 95-98. http://dx.doi.org/10.1016/0097-8485(83)85001-3

[14] Nardelli, M. (1995) PARST95-An Update to PARST: A System of Fortran Routines for Calculating Molecular Structure Parameters from the Results of Crystal Structure Analyses. Journal of Applied Crystallography, 28, 659. http://dx.doi.org/10.1107/S0021889895007138

[15] Bernstein, J., Davis, R.E., Shimoni, L. and Chamg, N.-L. (1995) Patterns in Hydrogen Bonding: Functionality and Graph Set Analysis in Crystals. Angewandte Chemie International Edition (English), 34, 1555-1573.

http://dx.doi.org/10.1002/anie.199515551

\section{Supplementary Materials}

CCDC-1026953 and CCDC-810386 contain the supplementary crystallographic data for compound 1 and 2, respectively. These data can be obtained free of charge via https://www.ccdc.cam.ac.uk/getstructures, by e-mailing data_request@ccdc.cam.ac.uk, or by contacting The Cambridge Crystallographic Data Centre, 12 Union Road, Cambridge CB2 1EZ, UK, fax; +44 (0)1223-336033. 